\title{
Analysis and Design of deep beam by using Strut and Tie Method
}

\author{
Niranjan B.R ${ }^{1}$, Patil S.S ${ }^{2}$ \\ ${ }^{1}$ Professor, Civil Engineering Department.,U.V.C.E. Bangalore University Bangalore. India. \\ ${ }^{2}$ Associate Professor, Civil Engineering Department, Walchand Institute of Technology. Solapur India.
}

\begin{abstract}
Experimental research was conducted to determine the strength of deep beam designed by using strut -and-tie method. The work was done in two phases. The first phase consists of design of simply supported deep beams by using Strut and Tie Method for various shear span to depth ratios. In the second phase several R.C. deep beams were cast and tested in heavy structures Lab. Experimental results were compared with the theoretical results obtained by finite strip method.
\end{abstract}

Keywords : Strut and Tie method(STM); Deep beam; Finite strip method (FSM).

\section{INTRODUCTION.}

Flexural members can be broadly divided into two regions, namely, B (or Bernoulli) regions where the strain distributions are linear, and D (or Disturbed) regions where the strain distributions are non- linear. While well defined theories are available for designing B regions, thumb rule or empirical equations are still being used to design D regions, though $\mathrm{B}$ and $\mathrm{D}$ regions are equally important. It has been recently understood that the strut and tie method (STM) is an effective tool for the design of both B and D regions. Since the STM is a realistic approach, this has found place in many codes like American code, Canadian code and New Zealand code.

Strut-and-tie modeling provides design engineers with a more flexible and intuitive option for designing structures, or portions thereof, that are heavily influenced by shear. The method allows for the stress flows within a structure to be approximated with simple truss-elements that can be designed using basic structural mechanics.

\section{REASERACH SIGNIFICANCE.}

The objective of this investigation is an experimental study on strength \& behavior of deep beams. The detailed analysis has been carried out using the finite strip method.

The objectives of the experimental investigation can be listed as,

1. To observe \& explain the deflection, cracking \& failure modes of deep beams subjected to two point loading.

2. To compare the flexural steel requirement as per strut and tie method with that calculated using the finite strip method.

3. To comment on suitability of finite strip method \& strut and tie method.

4.

\section{The COMPUTER Program.}

The computer program has been prepared for the analysis of Deep Beam having simple support. A computer program is necessary for the solution of Equations. Computer program is developed on the basis of direct stiffness method.

The essential steps in writing a program are as follows.

1) Presenting input data to computer

2) Evaluation of stiffness matrix of individual strips.

3) Assembling of structure stiffness matrix

4) Forming the load vector

5) Solving the assembled equations for the displacements.

6) Computing the internal forces in the members and reactive forces at the support.

7) Presentation of the results.

Features of the Program

1. The programming language used is FORTRAN77.

2. The program can handle any number of joints and members depending upon memory allocations available with PC.

3. The program can handle yielding of the support in all three directions. Also it can handle symmetric structures in-plane, point load loads etc. 


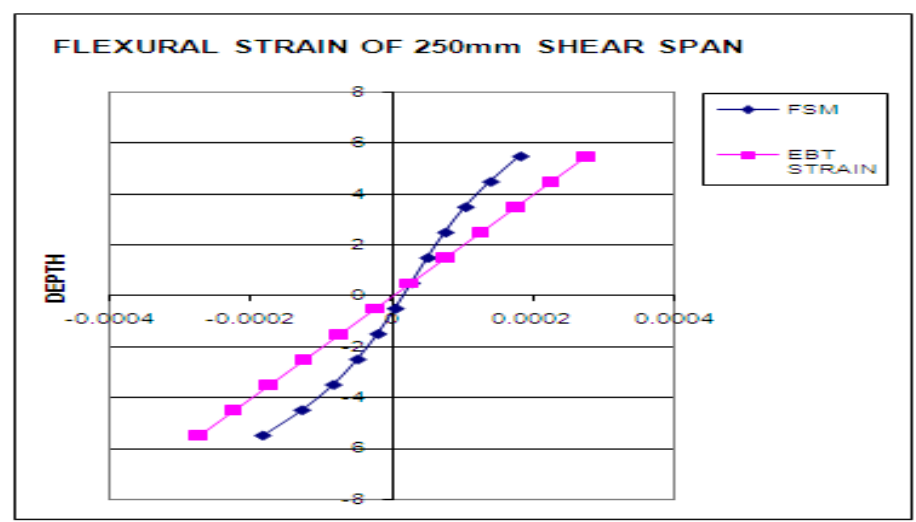

Fig 1. Flexural Strain Distribution of Shear span-to-depth ratio 0.71 .

\section{VARIATION OF FLeXURAL STRAin.}

The parametric study to know strain distribution in case of deep beam is performed here. It is found that the smaller the span/depth ratio (i.e., less than2.0), the more pronounced the deviation of the strain pattern from t hat of Euler Bernoulli theory. Figure 1. to Figure 4.shows that the flexural strain at mid span of simply supported deep beam for different shear span -to-depth ratios. The beams have disturbed region in flexural strain distribution. Deep beams behave differently from shallow beams. In these members, the distribution of strain across the depth of the cross section is nonlinear and a significant amount of load is carried to the supports by a compression strut joining the load and the reaction. These structural elements belong to $\mathrm{D}$ (disturbed) regions. Structural members can be broadly divided into two regions, namely, B (or Bernoulli) regions where the strain distributions are linear, and D (or Disturbed) regions where the strain distributions are non-linear. While well defined theories are available for designing B regions, thumb rule or empirical equations are still being used to design D regions, though B and D regions are equally important. Schlaich et al. (1987) identified deep beams as discontinuity regions where the strain distribution is significantly nonlinear and specific strutand-tie models need to be developed, whereas shallow beams are characterized by linear strain distribution and most of the applied load is transferred through a fairly uniform diagonal compression field.

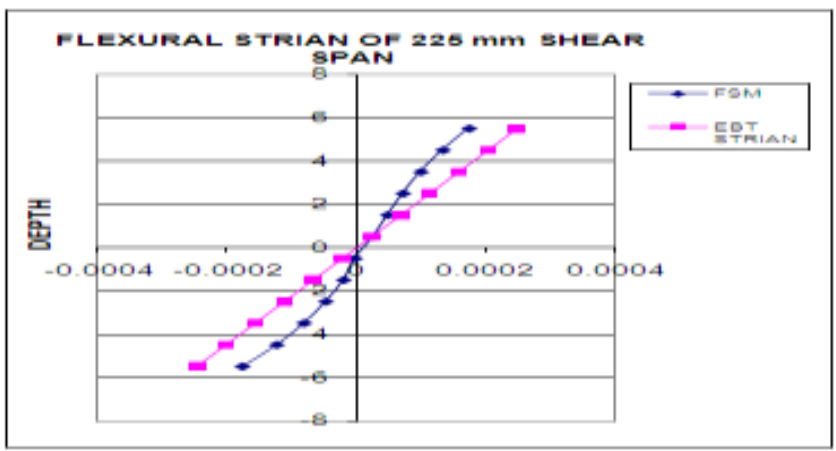

Fig 2. Flexural Strain Distributions Shear span-to-depth ratio 0.64

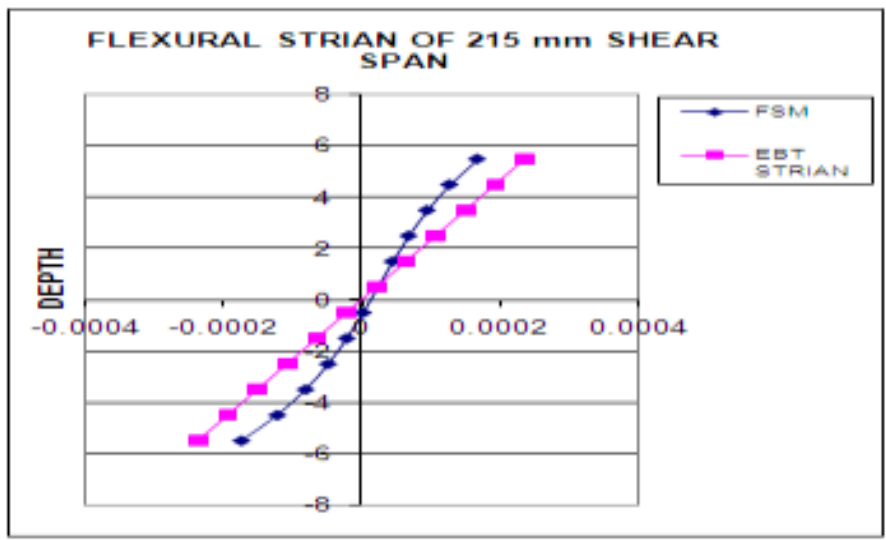

Fig 3. Flexural Strain Distribution Shear span-to-depth ratio 0.61. 


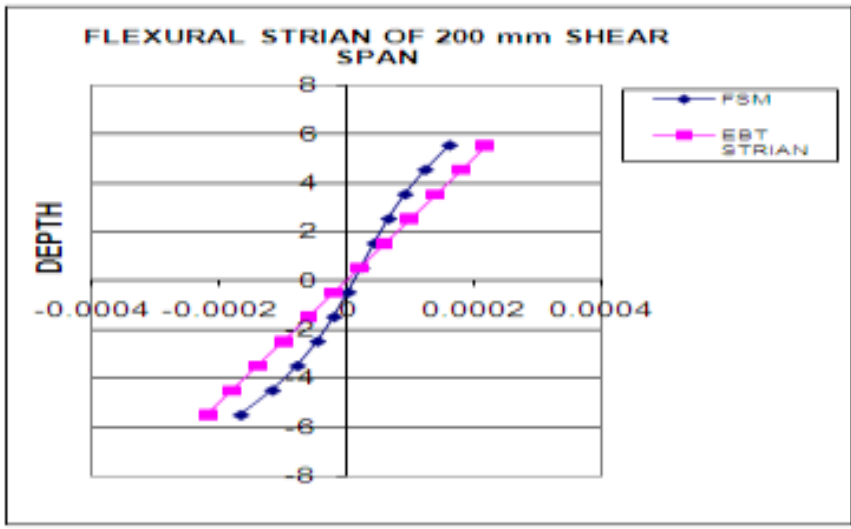

Fig 4. Flexural Strain Distribution Shear span-to-depth ratio 0.57.

From the variation of flexural strain graphs the definition of simply supported deep beam as per IS 456:2000 i.e. when $\mathrm{L} / \mathrm{D}$ ratio is less than or equal to 2.0 is reasonably accurate.

\section{VARIATION OF FLEXURAL STRESS.}

The stresses in isotropic homogeneous deep beams can be determined using finite strip analysis. It is found that the smaller the span/depth ratio (i.e., less than2.0), the more pronounced the deviation of the stress pattern from that of Euler Bernoulli theory. Figure 5.to Figure 8. shows the flexural stress at mid span of simply supported deep beam for different shear span -to-depth ratios. The compressive stresses increase rapidly at the top and neutral axis moves towards soffit of the beam.

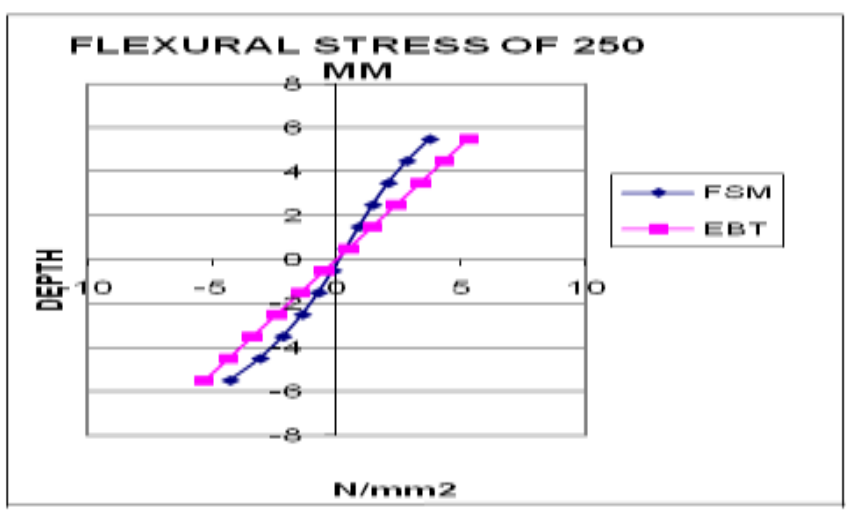

Fig 5. Flexural Stress Distribution Shear span-to- depth ratio 0.71 .

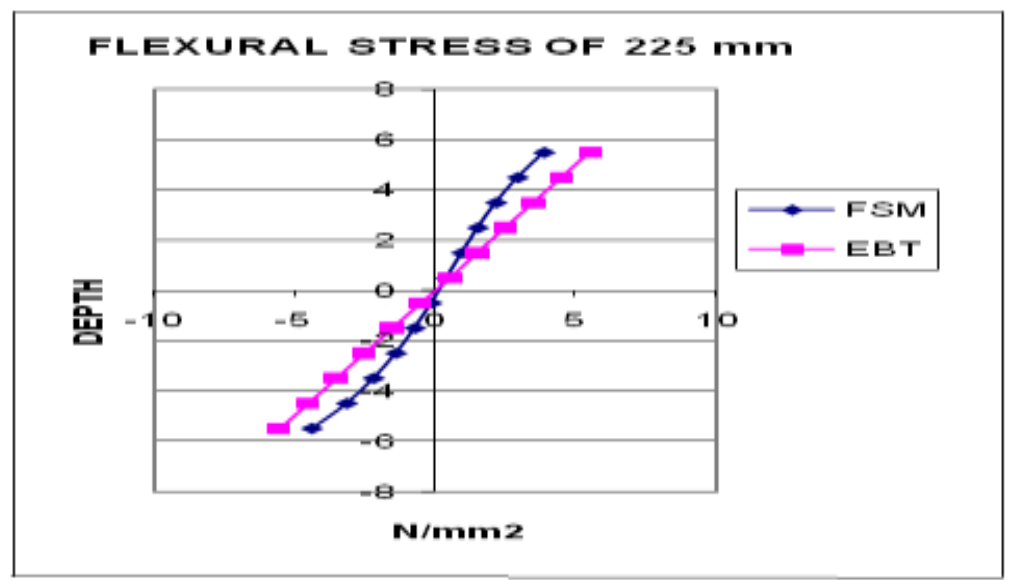

Fig 6. Flexural stress Distribution shear span to depth ratio 0.64 . 


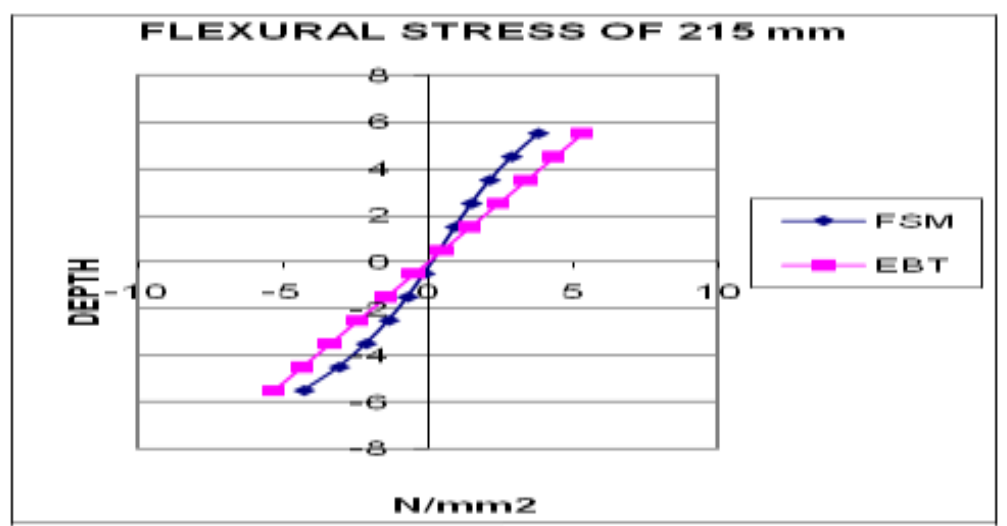

Fig 7. Flexural stress Distribution shear span to depth ratio 0.61 .

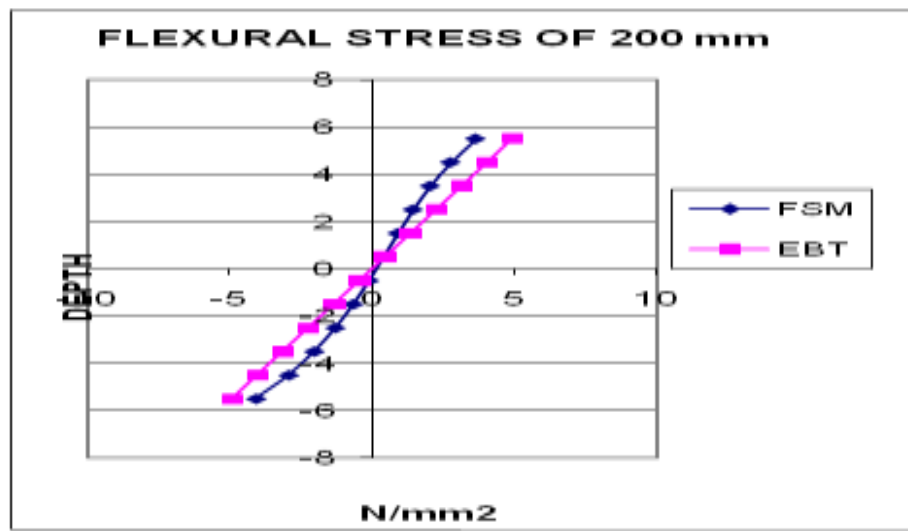

Fig 8.Flexural stress Distribution shear span to depth ratio 0.57.

'From the variation of flexural stress graphs the definition of simply supported deep beam as per IS 456:2000 i.e. when $\mathrm{L} / \mathrm{D}$ ratio is less than or equal to 2.0 is reasonably accurate.

\section{VARIATION OF FleXURAL STRESS.}

Figure 9. to Figure 12. shows the shear stress near support of simply supported deep beam for different shear span -to-depth ratios .The beams have drastic change in shear stress distribution. Deep beams behave differently from shallow beams. The shear stress patterns have also changed in case of deep beam. It is found that the smaller the span/depth ratio (i.e., less than2.0), the more pronounced the deviation of the shear stress distribution from that of Euler Bernoulli theory.

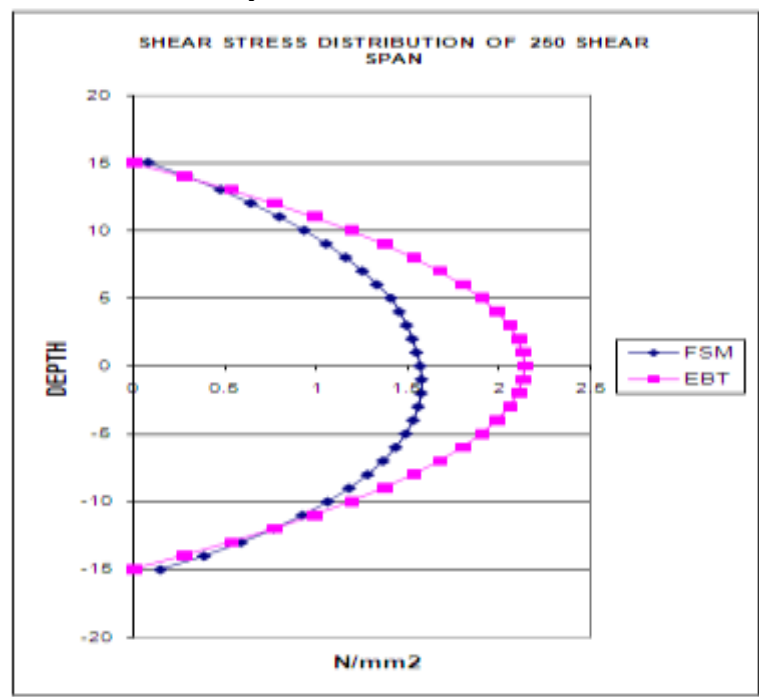

Fig 9. Shear Stress Distribution shear span-to-depth ratio 0.71 . 
SHEAR STRESS DISTRIBUTION OF 225 mm SHEAR SPAN

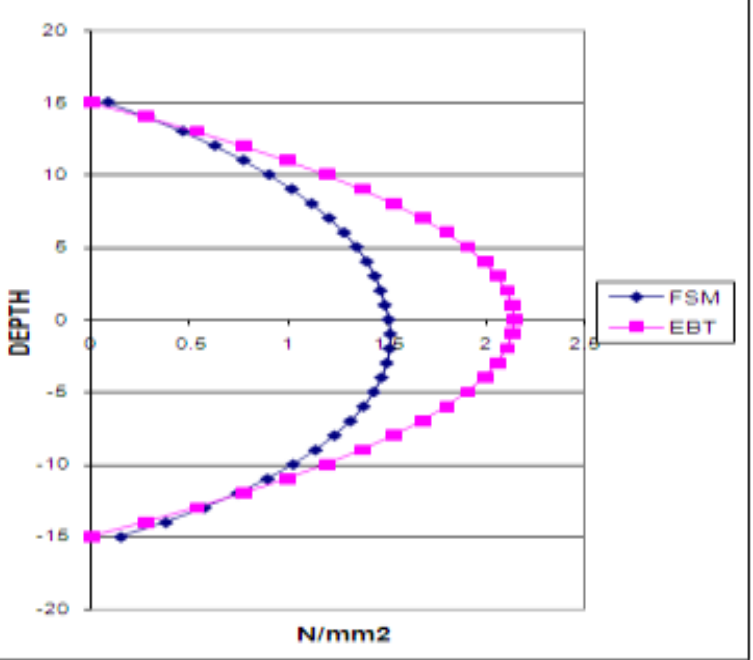

Fig 10. Shear Stress Distribution shear span-to-depth ratio 0.64.

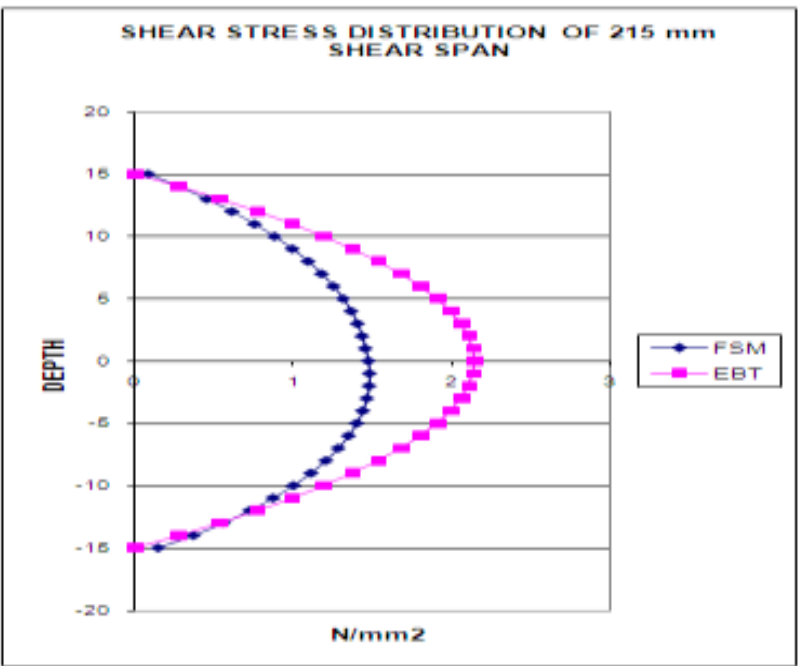

Fig 11. Shear Stress Distribution shear- span-to depth ratio 0.61.

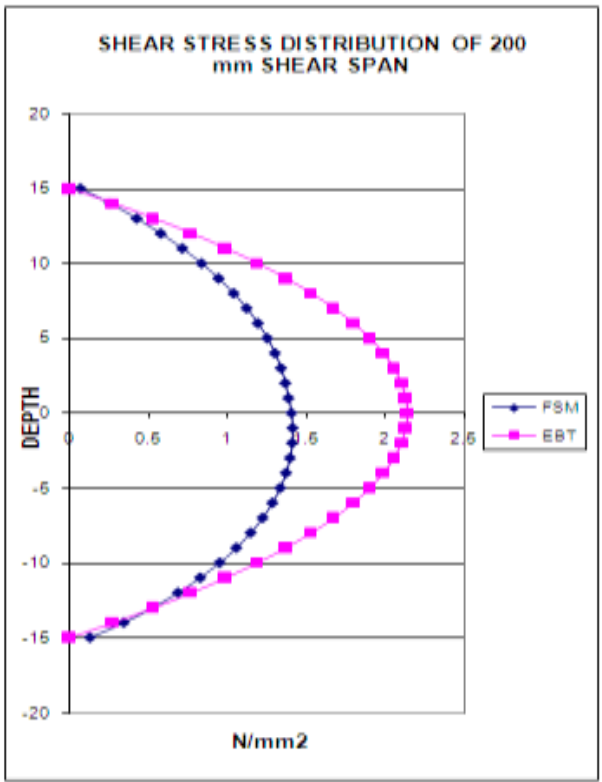

Fig 12. Shear Stress Distribution shear- span-to depth ratio 0.57. 
Analysis and Design of deep beam by using Strut and Tie method

From the variation of shear stress graph it is clear that shear effect is predominant in beams having L/D ratio less than or equal to 2.0 which may lead to warping of the section.

VII. TENSION REINFORCEMENT CALCULATIONS From GRAPH .

The reinforcement required for various shear spans were determined by using FSM and are tabulated in Table 1 to 4 .

Table 1. Reinforcement required for Shear span $250 \mathrm{~mm}$

\begin{tabular}{|l|l|l|}
\hline Sr.No & Strip No. & Reinforcement required $\mathbf{~ m m}^{2}$ \\
\hline 1 & 1 & 0.96 \\
\hline 2 & 2 & 10.032 \\
\hline 3 & 3 & 19.296 \\
\hline 4 & 4 & 30.32 \\
\hline 5 & 5 & 43.805 \\
\hline 6 & 6 & 60.55 \\
\hline \multicolumn{2}{|c|}{ TOTAL } & $\mathbf{1 6 4 . 9 7} \mathbf{~ m m 2}$ \\
\hline
\end{tabular}

Table 2. Reinforcement required for Shear span $225 \mathrm{~mm}$

\begin{tabular}{|c|c|c|}
\hline Sr.No & Strip No. & \multicolumn{2}{|l|}{$\begin{array}{l}\text { Reinforcement required } \\
\mathbf{m m}^{\mathbf{2}}\end{array}$} \\
\hline 1. & 1 & 0.918 \\
\hline 2. & 2 & 9.6 \\
\hline 3. & 3 & 18.456 \\
\hline 4. & 4 & 29 \\
\hline 5. & 5 & 41.576 \\
\hline 6. & 6 & 57.92 \\
\hline & Total & $\mathbf{1 5 7 . 4 7} \mathbf{m m}^{\mathbf{2}}$ \\
\hline
\end{tabular}

Table 3. Reinforcement required for Shear span $215 \mathrm{~mm}$

\begin{tabular}{|c|c|c|}
\hline Sr.No & Strip No. & Reinforcement required $\mathbf{~ m m}^{2}$ \\
\hline 1. & 1 & 0.897 \\
\hline 2. & 2 & 9.375 \\
\hline 3. & 3 & 18.0307 \\
\hline 4. & 4 & 28.33 \\
\hline 5. & 5 & 40.62 \\
\hline 6. & 6 & 56.585 \\
\hline & Total & $\mathbf{1 5 3 . 8 4} \mathbf{~ m m}^{2}$ \\
\hline
\end{tabular}

Table 4. Reinforcement required for Shear span $200 \mathrm{~mm}$

\begin{tabular}{|c|c|c|}
\hline Sr.No & Strip No. & $\begin{array}{l}\text { Reinforcement } \\
\text { required } \mathbf{m m}^{2}\end{array}$ \\
\hline 1. & 1 & 0.86 \\
\hline 2. & 2 & 8.99 \\
\hline 3. & 3 & 17.3 \\
\hline 4. & 4 & 27.183 \\
\hline 5. & 5 & 38.973 \\
\hline \multirow[t]{2}{*}{6.} & 6 & 54.293 \\
\hline & Total & $147.6 \mathrm{~mm}^{2}$ \\
\hline
\end{tabular}

VIII. DESIGN OF DEEP BEAMS.

to depth ratio.

Design by using ACI-Appendix A Strut \& Tie method (STM) was carried out with various shear span

Dimensions of Deep beams chosen for design purpose are,

Length $=700 \mathrm{~mm}$,

Depth $=350 \mathrm{~mm}$,

Thickness $=150 \mathrm{~mm}$

Testing in Heavy Structural laboratory for two point loads. The several specimens were cast as shown in Fig. 13 and tested in heavy structural laboratory for two point loading as shown in Fig.14. 


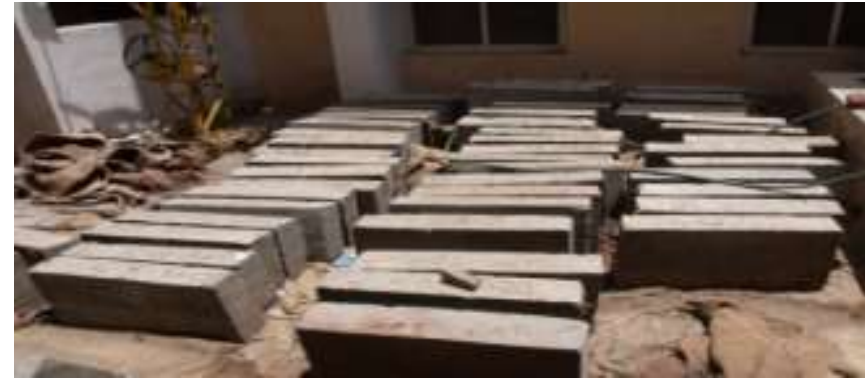

Fig. 13.Specimens of deep beam.

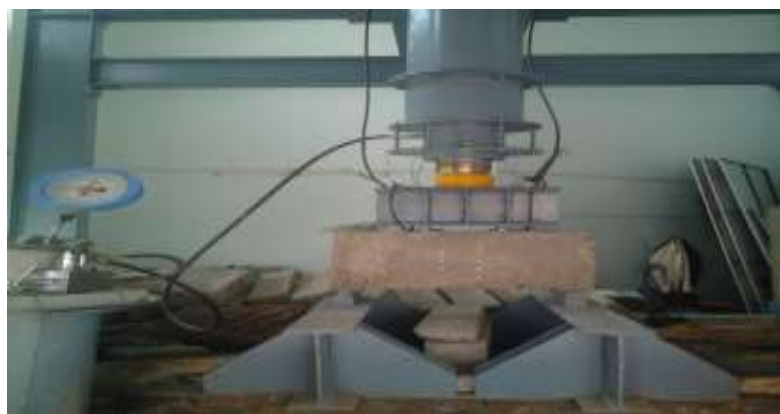

Fig. 14.Experimental test set up.

IX.

SAMPLE TEST RESULTS.

The average sample test results were presented in Table .5 .

Table.5.Sample Test Results for two point loading over beam designed by STM.

\begin{tabular}{|c|c|c|c|c|c|}
\hline \multicolumn{2}{|c|}{ Shear span $(\mathrm{mm})$} & 250 & 225 & 215 & 200 \\
\hline \multicolumn{2}{|c|}{$\begin{array}{l}\text { Shear span to depth } \\
\text { ratio }\end{array}$} & 0.71 & 0.642 & 0.614 & 0.571 \\
\hline \multirow{3}{*}{$\begin{array}{l}\text { Reinf } \\
\text { orcem } \\
\text { ent } \\
\text { (No.of } \\
\text { bars) }\end{array}$} & $\begin{array}{l}\text { Flexure steel } \\
\text { Required in } \\
\mathrm{mm}^{2}\end{array}$ & 215.89 & 194.30 & 183.59 & 169.52 \\
\hline & $\begin{array}{l}\text { Flexure } \\
\text { provided } \\
\text { i) } 08 \mathrm{~mm}^{2} \Phi \\
\text { ii) } \mathrm{mm}^{2}\end{array}$ & $\begin{array}{c}5 \\
251.20\end{array}$ & $\begin{array}{c}4 \\
200.96\end{array}$ & $\begin{array}{c}4 \\
200.96\end{array}$ & $\begin{array}{c}4 \\
200.96\end{array}$ \\
\hline & $\begin{array}{l}\text { Shear } \\
6 \mathrm{~mm} \text { dia. }\end{array}$ & $\begin{array}{l}5 \\
3\end{array}$ & $\begin{array}{l}5 \\
3\end{array}$ & $\begin{array}{l}5 \\
3\end{array}$ & 5 \\
\hline \multicolumn{2}{|c|}{$\begin{array}{l}\text { Load at first crack } \\
\text { Load at each point }(\mathrm{kN})\end{array}$} & $\begin{array}{c}190 \\
95\end{array}$ & $\begin{array}{l}200 \\
100\end{array}$ & 208 & $\begin{array}{l}224 \\
112\end{array}$ \\
\hline \multicolumn{2}{|c|}{$\begin{array}{l}\text { Failure Load (kN) } \\
\text { i) } \quad \text { Permissible } \\
\text { Load } \\
\text { ii) } \quad \text { UTM } \\
\text { iii)Load at each point }\end{array}$} & $\begin{array}{c}160.93 \\
314 \\
157\end{array}$ & $\begin{array}{c}160.93 \\
324 \\
162\end{array}$ & $\begin{array}{l}160.93 \\
164\end{array}$ & $\begin{array}{l}160.93 \\
340 \\
170\end{array}$ \\
\hline \multicolumn{2}{|c|}{$\begin{array}{l}\text { i)Permissible } \\
\text { Deflection } \\
\text { ii)Deflection @ 150KN } \\
\text { iii)Deflection at failure } \\
\text { (mm) }\end{array}$} & $\begin{array}{l}2.4 \\
1.15 \\
2.5\end{array}$ & $\begin{array}{c}2.4 \\
1.34 \\
3\end{array}$ & $\begin{array}{l}.4 \\
1.21 \\
3.75\end{array}$ & 1.09 \\
\hline \multicolumn{2}{|c|}{$\begin{array}{l}\text { Observed mode of } \\
\text { failure }\end{array}$} & $\begin{array}{l}\text { Compression } \\
\text { failure of struts }\end{array}$ & $\begin{array}{l}\text { Compression } \\
\text { failure of struts }\end{array}$ & $\begin{array}{l}\text { Compression } \\
\text { failure of struts }\end{array}$ & $\begin{array}{l}\text { Compression } \\
\text { failure of } \\
\text { struts }\end{array}$ \\
\hline
\end{tabular}




\section{CONCLUSION}

1. The strut and tie model helps to understand the behavior of the structural elements and will be extremely useful for detailing reinforced concrete members.

2. Self-weight of the beams may be very small in comparison to the concentrated loads supported by the beam. Therefore the study is significant for the cases where concentrated loads have to be supported by deep beams.

3. In design the flexural steel requirements directly proportionally to the shear span of deep beam.

4. The shear strength of deep beam increases with decreasing shear span-to-depth ratio. The shear strength of deep beams were $314 \mathrm{kN}, 324 \mathrm{kN}, 328 \mathrm{kN}, 340 \mathrm{kN}$ for various shear span- to-depth ratio $0.71,0.64,0.61$ and 0.57 respectively.

5. All the beams had low deflection at failure as there was no flexural failure.

6. Mode of failure of deep beam was mainly shear failure only.

7. The strut and tie model, it was observed that the force in the bottom member is constant throughout its length. Further this implies that the reinforcement provided at the mid-span should not be curtailed and must be extended up to the support

8. The flexural steel required by strut and tie method was $15 \%$ to $30 \%$ more than determined by finite strip method for shear span $200 \mathrm{~mm}$ to $230 \mathrm{~mm}$.

9. The overall average load at first crack was approximately half of the ultimate failure load. Therefore in design of deep beam by using Strut and Tie Method, load factor of 1.2 for dead load \& load factor 1.6 for live load seems to be reasonable.

\section{REFERENCES}

[1] Plain and Reinforced Concrete - Code of Practice'. Bureau of Indian Standards, Manak Bhavan, New Delhi, India

[2] ACI 318-05. 'Building Code Requirements For Structural Concrete and Commentary' American Concrete Institute, Detroit, USA.

[3] J Schliach and K Schafer.' Design and Detailing of Structural Concrete using Strut-and-Tie Models'. The Structural Engineer,vol 69, 1991, 113

[4] AASHTO, "AASHTO LRFD Bridge Specifications for Highway Bridges" (2001 Interim Revisions), American Association of Highway and Transportation Officials, Washington, D.C., 1998.

[5] Mr. Varghese and Mr. Krishnamoorthy,(1966),Streingth and Behaviour of Deep Reinforced Concrete Beams, Indian Concrete Journal, 104-108.

[6] Matamoros and Wong,(2003), Design of simply supported Deep beam using strut -and -tie models,ACI Structural journal,704712.

[7] Quintero-Febres, Parra-Montesinos and Wight,(2006), Strength of Struts in deep Concrete Members Designed Using Strut and Tie Method, ACI Structural journal, 577-586.

[8] Park and pauly, Reinforced Concrete Structures, A wiely-Interscience Publication.

[9] P. Nagarajan, Dr.T.M.M.Pillai and Dr.N.Ganesan, (2007), Design of Simply Supported Deep Beams using IS 456:2000 and Strut and Tie Method, IE (I) Journal-CV, 38-43.

[10] Michael D. Brown, Cameron L. Sankovich, Oguzhan Bayrak,James O. Jirsa,John E. Breen, Sharon L. Wood, (2006), the technical report on Design for Shear in Reinforced Concrete Using Strut -and-Tie Models.

[11] James k Wight and Gustavo J.Parra-Montesinos,(2003), Strut-And-Tie Model For Deep Beam Design, Concrete international,6370.

[12] Perry Adebar and Zongyu Zhou,(1993),Bearing Strength of Compressive Struts Confined by Plain Concrete, ACI Structural Jouranal,534-541.

[13] Chung, W., and Ahmad, S.H., 1994, "Model for Shear Critical High-Strength Concrete Deep Beams," ACI Structural Journal, Vol. 91, No. 1, pp. 31-41.

[14] Laupa, A., Siess, C.P., and Newmark, N.M., 1953, "The Shear Strength of Simple-Span Reinforced Concrete Beams without Web Reinforcement,"Structural Research Series No. 52, University of Illinois, Urbana.

[15] 15. Morrow, J., and Viest, I. M., 1957, "Shear Strength of Reinforced Concrete Frame Members Without Web Reinforcement," ACI Journal, V.53, No. 9, pp. 833-869. 